\title{
Ecological Sustainability of Detar (Detarium senegalense J. F. Gmel) in Togo (West Africa)
}

\author{
Fifonsi Ayélé Dangbo1* ${ }^{*}$ Kossi Adjonou${ }^{1}$, Kouami Kokou', Juergen Blaser ${ }^{2}$ \\ ${ }^{1}$ Forest Research Laboratory, Faculty of Sciences, University of Lome, Lome, Togo \\ ${ }^{2}$ Forest and Climate Change Department, Bern University of Applied Science (HAFL), Bern, Switzerland \\ Email: ^fifonsidangbo@gmail.com, kossiadjonou@hotmail.com, kokoukouami@hotmail.com, juergen.blaser@bfh.ch
}

How to cite this paper: Dangbo, F.A., Adjonou, K., Kokou, K. and Blaser, J. (2019) Ecological Sustainability of Detar (Detarium senegalense J. F. Gmel) in Togo (West Africa). American Journal of Plant Sciences, 10, 417-432.

https://doi.org/10.4236/ajps.2019.103030

Received: October 31, 2018

Accepted: March 10, 2019

Published: March 13, 2019

Copyright $\odot 2019$ by author(s) and Scientific Research Publishing Inc. This work is licensed under the Creative Commons Attribution International License (CC BY 4.0).

http://creativecommons.org/licenses/by/4.0/

\begin{abstract}
Detarium senegalense J. F. Gmel., of the family of Fabaceae is one of the most exploited tree species in Togo. However, there are only few scientific studies on the distribution of this specie. This study is a contribution to the promotion of multi-purpose tree species in Togo with particular emphasis on a better knowledge of Detarium senegalense. It provides data on the ecology of the specie and his state of regeneration. The data on the specie are based on sample plots in the areas identified as hosts of the specie in Togo. A total of 77 circular plots of $1000 \mathrm{~m}^{2}$ (17.8 m radius) were established in ecological zones II, IV and V of Togo. The dendrometric parameters identified are: the total height and diameter at breast height (DBH) of Detarium senegalense and of all species found in each plot. Detarium senegalense trees of $\mathrm{DBH}<10 \mathrm{~cm}$ are considered as potential regenerations. Detarium senegalense is more abundant in zones IV (forest area), followed by zone II. In zone V, Detarium senegalense is located only in the forest of "Have". The structure of Detarium senegalense has a bell-shaped distribution with predominance of trees with large and intermediate diameters ranging between 30 and $70 \mathrm{~cm}$. Trees of small DBH $(<30 \mathrm{~cm})$ are often lacking in natural forest stands where Detarium senegalense occurs. This indicates a low regeneration rate of the specie. However, the structure of all species inventoried has a negative exponential distribution with predominance of small diameter trees. The sustainable management of Detarium senegalense in the forest can only be secured through a sustainable harvesting of seeds and actives promotion of natural regeneration.
\end{abstract}

\section{Keywords}

Detarium senegalense, Distribution, Ecology, Non-Timber Forest Products, Togo 


\section{Introduction}

The harvesting of forest products, wood and non-timber forests products (NTFPs), has increased considerably [1], resulting in overexploitation of many species and the degradation of their environment. Overexploitation of resources is a threat as it can lead to an irreversible loss of species, genetic diversity and an increase of vulnerability to climate change. Many studies [2]-[7] have shown the ecological importance of NTFPs such as those from Adansonia digitata, Irvingia gabonensis/Irvingia wombolu, Dacryodes edulis, Ricinodendron heudelotii, Garcinia kola, Chrysophyllum albidum, Cola spp., etc. in West Africa. In many rural communities, especially in the dry tropics, people depend solely on agriculture and marketing of NTFPs for their income and support themselves [8]. Income from NTFPs (particularly from species such as Dacryodes edulis, Canarium schweinfurthii, Arthocarpus spp., Ricinodendron heudelotii, Gambeya africana) may become even more important in remote rural households in West African countries, which are characterized by rapid economic growth, population expansion and constant change [9] [10]. Therefore, sustainable harvesting of NTFP is not only essential for conservation of the plant species, but also for the livelihoods of many rural peoples [11].

Among forest species, Detarium senegalensis is one of the most exploited tree species in West Africa, particularly in Togo [12]. The specie has long been exploited for timber [13] in Togo. The local population uses different parts of the tree [14] such as fruits, seeds and wood. The wood is used in house construction for planks, posts, poles and piles, and for furniture, fences, mortars, tool handles, boat-ribs and canoes [15]. Detarium senegalensis fruits have the most economic value and have therapeutic properties for treating coughs, kidney pain and leprosy [14] [16] [17]. Indeed, these fruits can help improve the livelihoods of local populations, as they are rich in nutrients [18]. Detarium senegalense is used for its medicinal properties and sale of seeds is said to be economically promising [19]. In Togo Detarium senegalense seeds are subject to international trade [19]. It has also been shown that Detarium senegalense has become a highly sought tree in the country and is subject to collective harvest in which even men are now involved (traditionally, this activity is done by women).

However, as for most of NTFPs, data and statistics on Detarium senegalense are scarce and often incomplete. The lack of data on density, yields and annual variations makes it impossible to be confident about the sustainability of future supplies [20]. The constant pressures on forest resources are risks to the survival of Detarium senegalense in natural forests of Togo [21]. Indeed, the continuing destruction of its ecological niche is clearly a threat to the survival of the species in the long term (ibid). Unfortunately, there are only few scientific studies related to the impact of fruit harvesting on the regeneration capacity of the species producing NTFPs [22]. Based on both these observations and previous works, a number of research questions arise such as: what are spatial distribution and ecology of Detarium senegalense in Togo? What is its regeneration capacity and 
sustainability in today's constantly changing environment?

To establish a good policy for the conservation of specie, this information is very important because it helps in identifying potential areas where the specie is abundant and thus directs the choice of areas where special conservation measures of the specie can be undertaken [23]. Therefore, the general objective of this study is to contribute to the promotion of multi-purpose tree species in Togo with particular emphasis on a better understanding of ecological behavior of Detarium senegalense. The specific objectives are: 1) to characterize the spatial distribution, ecology and sustainability of Detarium senegalense in heavily degraded forest areas of Togo; 2 ) to analyze the factors influencing its regeneration (rate) in order to improve its potential of domestication.

\section{Methodology}

\subsection{Collection of Data on SPECIES INVENTORY}

The study of Detarium senegalense was carried out through forest inventories based on oriented sampling in areas identified as hosts of the species in Togo. A total of 77 plots were installed in ecological zones II, IV and V of Togo (Figure 1). In each identified area, circular plot of $1000 \mathrm{~m}^{2}$ (17.8 m radius) were installed as suggested by [24]. Detarium senegalense shown by the local population as the main source of fruit collection is placed in the center of each plot. A minimum distance of $500 \mathrm{~m}$ was maintained between two consecutive circles. The geographical coordinates of forest inventory plots were recorded using a GPS receiver. The diameter at breast height $(\mathrm{DBH})$ and the height of Detarium senegalense were measured in each plot respectively with a tape measure and a dendrometer Blume-Leiss. The main stand of the forest inventory is Detarium senegalense individuals with $\mathrm{DBH} \geq 10 \mathrm{~cm}$ and height $>130 \mathrm{~cm}$. Detarium senegalense individuals whose $\mathrm{DBH}<10 \mathrm{~cm}$ are considered as regenerations seedlings. The number of regeneration seedlings were counted in a circle of $4 \mathrm{~m}$ radius around the center of the main plot. The scientific name of all species found in each plot was noted. To characterize the ecology of trees, a listing of ecological descriptors was filled each time a plot was installed. This description concerned the topography, soil texture, the type of vegetation and the recovery of the surrounding strata. Determination of the soil type was based on soil texture and color. To realize the distribution map of Detarium senegalense trees in Togo, the geographical coordinates (longitude and latitude) of each Detarium senegalense were recorded using a GPS. These data were supplemented with secondary data mainly from previous research work done in the field by Adjonou [25] and Adjossou [26].

\subsection{Germination Tests of Detarium senegalense}

Seeds of Detarium senegalense were collected for germination tests as suggested by [27]. On a number of 50-pulped seeds from the market, 21, which had no defects over their entire surface, were selected for the test. They were put in a 


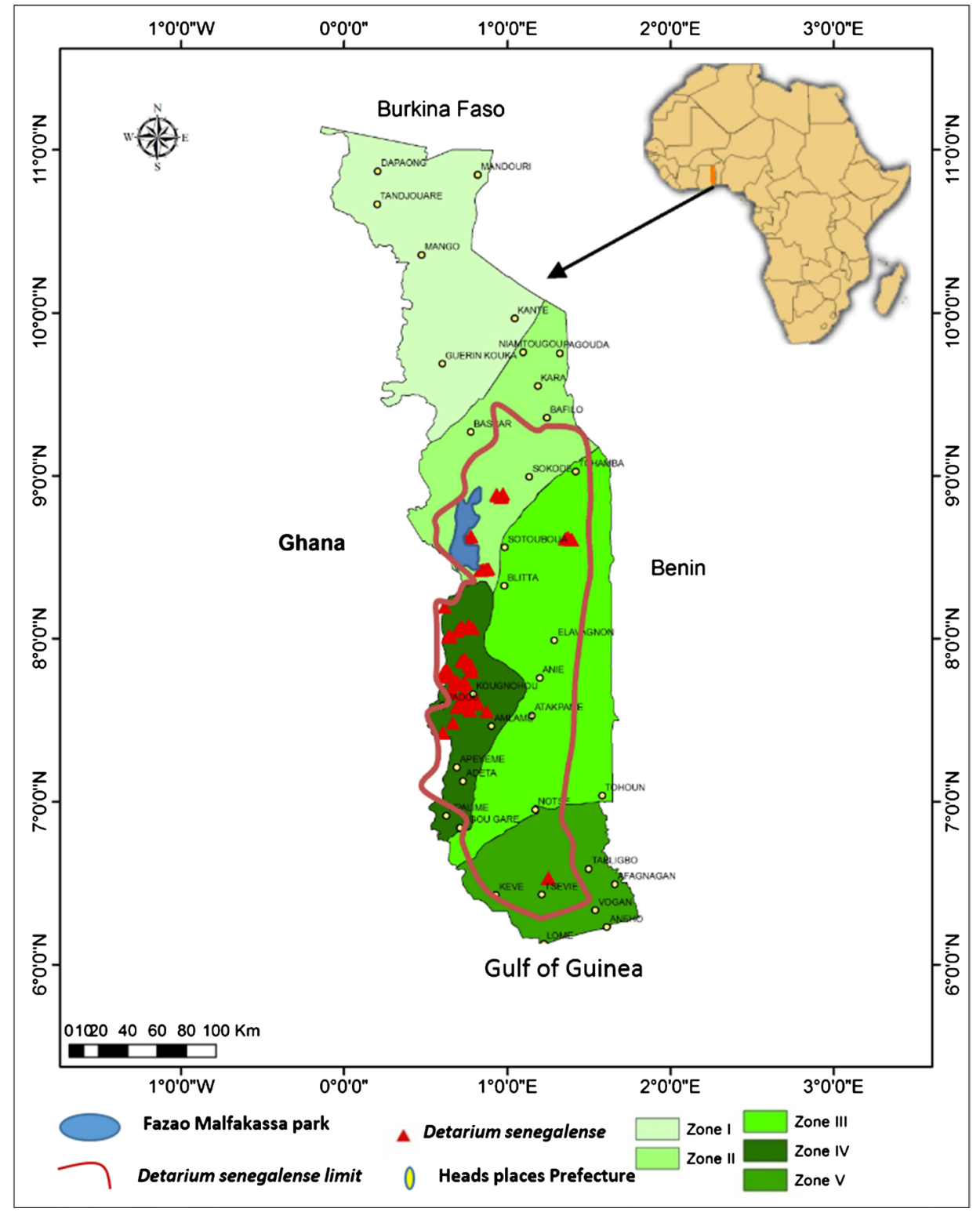

Figure 1. Study area and Detarium senegalense distribution in Togo.

seed-sprouting bag previously filled with sand from the dump. The germination conditions were covered: environment, mean temperature of $27^{\circ} \mathrm{C}$ and daily watering.

\subsection{Data Analysis}

\section{Dendrometric parameters}

The calculated parameters are density, basal area, mean diameter, mean height and frequency of Detarium senegalense individuals. Forest characteristics are appreciated by arithmetic calculation of the average diameter and the average height from measurements of forest inventory. After calculating these parameters, data processing occured by submitting the data collected on Detarium senegalense and other species to the analysis of variance to compare dendrometric parameters (diameter at breast height and total mean of height) according to 
the ecological areas considered. The software "R" was used to make Detarium senegalense diameters structure curve as well as the one from other species inventoried in different ecological areas. The Kruskal statistical test was used to test if there is a significant difference between the diameters and the heights of Detarium senegalense compared to other species inventoried in different ecological areas. The use of this non-parametric test can be explained by the fact that the data do not follow a normal distribution. When the p-value $<0.05$ then we reject the null hypothesis that there is no difference between the mean of DBH and heights of Detarium senegalense individuals and those of the others species. When the p-value $>0.05$, we considered the null hypothesis to be true.

Calculation of basal area, density and frequency of all species inventoried

The density $(\mathrm{N})$, basal area $(\mathrm{G})$ and frequency $(\mathrm{F})$ of Detarium senegalense in each ecological zone were calculated. The calculation of these parameters did not consider Detarium senegalense trees used as the center of plots. The inclusion of these individuals would have had a significant impact on the account settings given the inventory methodology used.

\section{Density}

The density is the average number of individuals estimated per hectare, it is calculated by the formula: $N=n / s$. number of individuals and $s$, the area covered (ha).

\section{Basal area}

Basal area $G$ is the sum of all cross sections of all tree species $1.30 \mathrm{~m}$ above the ground brought in $\mathrm{m}^{2} / \mathrm{ha}$. It is obtained by the following formula:

$$
G=\pi / 4 s \sum_{i=1}^{n} \mathrm{DBH}^{2} .
$$

With DBH (diameter at breast height; $\mathrm{m}$ ); $s$ the area covered (ha).

\section{Percentage of Detarium senegalense regeneration rate}

Calculating the rate of regeneration is performed for Detarium senegalense trees according to the following formula [28]:

$$
T=\frac{\text { Number individual species regenerated } \mathrm{DBH}<10 \mathrm{~cm}}{\text { Number individual } \mathrm{DBH}>10 \mathrm{~cm}}
$$

The "R" Version 3.03 software was used to estimate the parameters of the theoretical Weibull distribution from diameters of data. The Weibull distribution parameters $2(k$ and $\lambda$ ) is characterized by great versatility and a great form of variability has provided a better fit distribution curves. Its probability density function, $f(x)$ is in the form below [29]:

$$
f(x ; k, \lambda)=k / \lambda(x / \lambda)^{(k-1)} \mathrm{e}^{-(x / \lambda)^{k}}
$$

where $x$ is the diameter of trees and $f(x)$ the probability density value.

$k$ (shape) $>0$ is the shape parameter;

$\lambda$ (scale) $>0$ is the scale parameter or size.

The demographic structure of trees was determined by visualizing the histo- 
gram of species according to their distribution by diameter classes. The histogram was established with the abscissa classes of diameters and in ordinate the probability density of species. Chosen diameter classes are: $[10-30[\mathrm{~cm},[30-$ $50[\mathrm{~cm},[50-70[\mathrm{~cm},[70-90[\mathrm{~cm},[90-110[\mathrm{~cm} \ldots$ If the distribution histogram is consistent with a pace inverted J-shaped or decreasing exponentially, regeneration is good; in the opposite case, the regeneration comprises a disturbance. When it is bell-shaped, training is old. Specie shows good regeneration if they are present in all diameter classes. Analysis of the structure diameter of species was also made using boxplot. Theobroma cacao trees were not taken into account in the distribution of species in the ecological zone IV. This is because the study area is a Theobroma cacao planting area and the incorporation of this species would have a very great influence on the structure of the set of species.

\section{Result}

\subsection{Detarium senegalense Distribution in Togo}

Field data and secondary data collected shown that Detarium senegalense is present in the ecological zones II, III, IV and V of Togo, that means in dry (rainfall between 800 and $1100 \mathrm{~mm}$ ), subhumid (rainfall varies from 1400 to $1700 \mathrm{~mm}$ ) and humid (a rainfall of 1200 to $1500 \mathrm{~mm}$ ) areas. However, this study was performed in zone II, IV and V. The map (Figure 1) is highlightning the occurrence of the plant in Togo.

\subsection{Description of Detarium senegalense Habitat}

Detarium senegalense trees inventoried in this study are found in different topographical positions: mid-slope and down slope; less in the high slopes and flat areas. Inventoried trees are found in different types of soil (lateritic soils, waterlogged soils and little developed soils) but are more abundant in the lateritic soil $(60 \%)$. Detarium senegalense trees grow in different environments (gallery forests, dry forests, fallow, planting and woodlands) (Figure 2). However, the

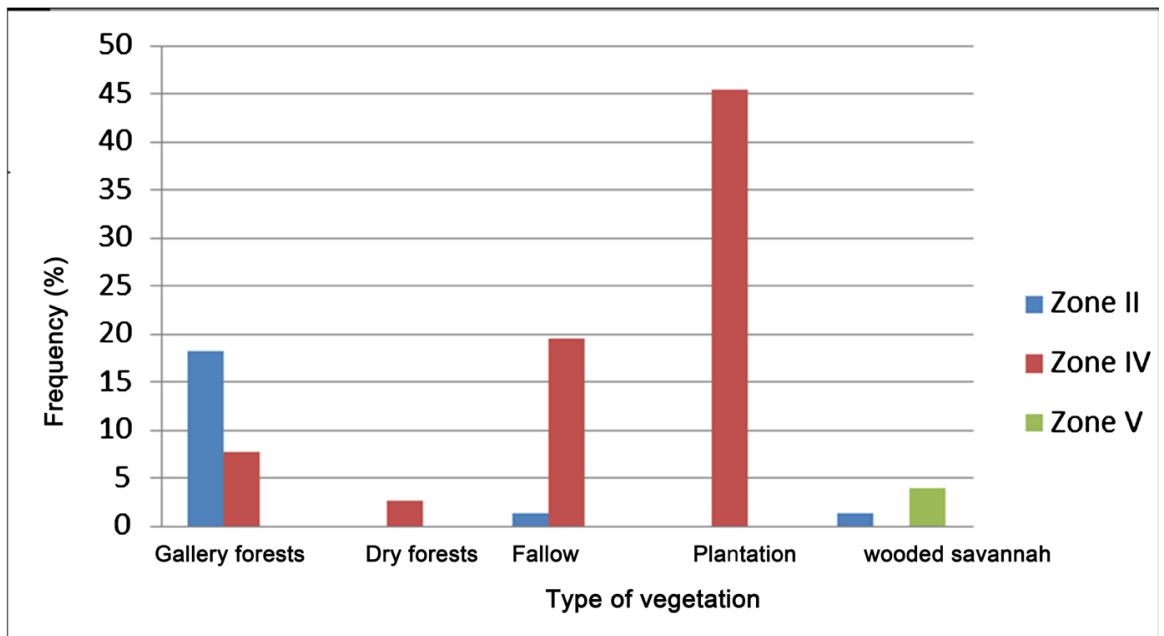

Figure 2. Presence of Detarium senegalense in different environment. 
main occurrence area of the Detarium senegalense is gallery forests and cocoa or coffee plantations.

\subsection{Stand Structures of All Species Inventoried}

Forest inventory identified in total 153 species divided into 44 families as being associated to Detarium senegalense. The most represented families are: Fabaceae (30), Moraceae (22), Euphorbiaceae (16), Rubiaceae (8), Anacardiaceae (7), Phyllantaceae (7) and Apocynaceae (7). The mean diameter of all species inventoried in all zone put together is $33.28 \pm 23.19 \mathrm{~cm}$. The mean diameter of all species is between $30.9 \pm 13.4 \mathrm{~cm}$ (zone V) and $38.5 \pm 25.2 \mathrm{~cm}$ (zone IV). In Zone II, the mean diameter is $34.2 \pm 24 \mathrm{~cm}$. There is no difference for this parameter in the three zones ( $\mathrm{p}$-value $=0.06>0.05$ ). The analysis of the mean height of all species shows different values depending on whether they are in Zones II, IV or V. The stands in Zone V $(9.9 \pm 3.6 \mathrm{~m})$ are significantly different (p-value $<0.001$ ) at the $5 \%$ probability level of those of the other two zones (Table 1).

All species were grouped by frequency class. Class I (1\% - 21\%) represents rare species; class II is the class of low frequency species $(21 \%-40 \%)$, class III is that of intermediate frequency species $(41 \%-60 \%)$, class IV is for medium frequencies $(61 \%-80 \%)$ and the class $\mathrm{V}$ is that of high frequencies. Most of species inventoried in zone II and IV have a frequency between $1 \%$ and $20 \%$ (Table 2). However, most of species inventoried in zone $\mathrm{V}$ have a frequency between $81 \%$ and $100 \%$.

Table 1. Characteristics of individuals of all trees observed for $\mathrm{DBH} \geq 10 \mathrm{~cm}$ in ecological zones II, IV and V of Togo.

\begin{tabular}{|c|c|c|c|c|c|}
\hline \multirow{2}{*}{\multicolumn{2}{|c|}{ Structural parameters }} & \multicolumn{3}{|c|}{ Zones } & \multirow{3}{*}{$\mathrm{p}$-value } \\
\hline & & \multirow{2}{*}{$\begin{array}{c}\text { Zone II } \\
257\end{array}$} & \multirow{2}{*}{$\begin{array}{c}\text { Zone IV } \\
626\end{array}$} & \multirow{2}{*}{$\begin{array}{c}\text { Zone } \mathrm{V}^{1} \\
46\end{array}$} & \\
\hline Observed trees & Number & & & & \\
\hline \multirow[t]{2}{*}{ Mean density (n/ha) } & Mean \pm STDEV & $160 \pm 63$ & $106 \pm 63$ & $220 \pm 113$ & \multirow[t]{2}{*}{-} \\
\hline & CV (\%) & 39 & 59 & 51.3 & \\
\hline \multirow{2}{*}{ Mean DBH $(\mathrm{cm})$} & Mean \pm STDEV & $34.2 \pm 24$ & $38.5 \pm 25.2$ & $30.9 \pm 13.4$ & \multirow[t]{2}{*}{$0.06>0.05$} \\
\hline & $\mathrm{CV}^{*}(\%)$ & 70.1 & 65.5 & 43.3 & \\
\hline \multirow{2}{*}{ Mean height (m) } & Mean \pm STDEV & $15.6 \pm 9$ & $13.6 \pm 7$ & $9.9 \pm 3.6$ & \multirow[b]{2}{*}{$5.817 \mathrm{e}-05<0.001$} \\
\hline & CV (\%) & 59.2 & 51.5 & 36.9 & \\
\hline \multirow{2}{*}{ Basal area ${ }^{2}\left(\mathrm{~m}^{2} / \mathrm{ha}\right)$} & Mean \pm STDEV & $21.2 \pm 12.4$ & $17.5 \pm 10.5$ & $13.9 \pm 3.5$ & \multirow{3}{*}{-} \\
\hline & CV (\%) & 58.7 & 59.6 & 24.9 & \\
\hline \multirow{3}{*}{$\begin{array}{l}\text { Percentile diameters } \\
\qquad(\mathrm{cm})\end{array}$} & $25 \%$ & 18.0 & 18.1 & 17.5 & \\
\hline & $50 \%$ & 26.3 & 32.8 & 31.5 & \\
\hline & $75 \%$ & 41.9 & 53.0 & 41.5 & \\
\hline
\end{tabular}

${ }^{1}$ Observation in a single forest (Have Forest); ${ }^{2}$ The calculation of the basal area did not take into account Detarium senegalense trees recorded in the different plots. 
The analysis of classes diameter distribution of all species inventoried indicates a different situation according to the ecological zone considered (Figure 3). This analysis took into account all inventoried species including Detarium senegalense trees inventoried between two consecutive plots. In all ecological zones, the diameter structure of inventoried species has a decreasing exponential shape distribution characterized by a dominance of young individuals (Figure 3(d)).

Table 2. Frequency class of inventoried species.

\begin{tabular}{ccccc}
\hline \multicolumn{2}{c}{ Frequency class } & Zone II & Zone IV & Zone V \\
\hline Class & Frequency (\%) & \multicolumn{3}{c}{ Species number } \\
\hline I & $1-20$ & 75 & 498 & 0 \\
II & $21-40$ & 4 & 78 & 0 \\
III & $41-60$ & 7 & 0 & 13 \\
IV & $61-80$ & 0 & 0 & 0 \\
V & $81-100$ & 1 & 0 & 30 \\
Total of effectifs & & 87 & 576 & 43 \\
\hline
\end{tabular}
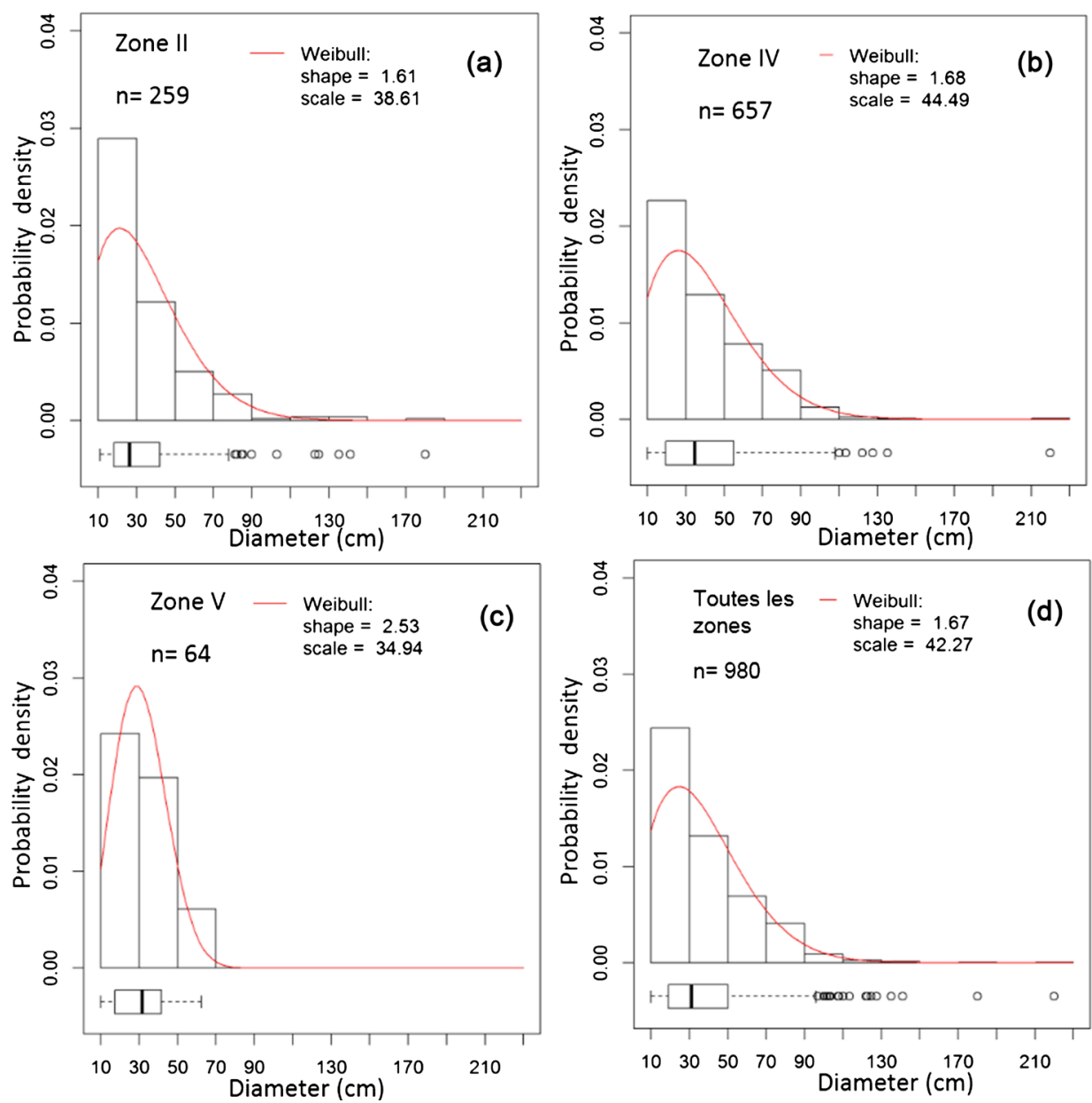

Figure 3. Distribution in diameter class and boxplot of all species inventoried in zone II (a), in zone IV (b), in zone V (c) and in all zones (d). 
This shows globally a high rate of regeneration of species in these forests. However, in zone II, individuals of small diameters are more abundant. This can be explained by the fact that the inventory in Zone II takes place mainly in the Fazao National Park which has a conservation status. In Zone II, the tree diameter class distribution shows a decreasing exponential shape distribution characterized by a dominance of small diameter trees (Figure 3(a)). In fact, the distribution of species diameter classes reveals a predominance of small diameter trees between 10 and $30 \mathrm{~cm}$. In this area $50 \%$ of species have a diameter of $25.3 \mathrm{~cm}$ (Table 1). This indicates a high rate of regeneration of the species. In addition, trees with diameters greater than $90 \mathrm{~cm}$ are very few represented in the stand. The distribution of species in zone IV is similar to that of zone II (Figure 3(b)). In this area $50 \%$ of species have a diameter of $32.8 \mathrm{~cm}$ and $75 \%$ of species have a diameter of $53 \mathrm{~cm}$ (Table 1). In zone V, the distribution of diameter classes of all species reveals a predominance of species with diameter classes between 10 and $50 \mathrm{~cm}$ (Figure 3(c)). In fact, $75 \%$ of species have a diameter less than $41.5 \mathrm{~cm}$ (Table 1). Species with a diameter greater than $50 \mathrm{~cm}$ are very little present in the zone which is a savannah.

\subsection{Stand Structure of Detarium senegalense}

Detarium senegalense trees structure vary according to ecological zone. The mean diameter of Detarium senegalense trees in all ecological zone put together is $58.42 \pm 19.79 \mathrm{~cm}$. The mean diameter of trees is between $43 \pm 9.6 \mathrm{~cm}$ (zone V) and $63.5 \pm 19 \mathrm{~cm}$ (zone IV). In zone II, the mean diameter is $54.8 \pm 21.4 \mathrm{~cm}$. The statistical Kruskal allowed comparing the DBH of Detarium senegalense in different ecological zones. This test gives a p-value $<0.001$. The difference is highly significant between the diameters of individuals from the three zones (p-value $<$ 0.001). Analysis of the mean height of Detarium senegalense shows significantly different values depending on whether it is in Zone II, IV or V. This allows saying that the stands of Detarium senegalense in different areas are different from each other (Table 3).

The analysis of Detarium senegalense classes distribution of diameter indicates a different position depending on the area considered ecological. In all ecological zones put together Detarium senegalense has a bell structure with a dominance of intermediate trees (Figure $4(\mathrm{~d})$ ). We noted that $50 \%$ of Detarium senegalense trees in all ecological zone have DBH $\leq 56.80 \mathrm{~cm}$ and $75 \%$ of trees with a diameter less than $70.75 \mathrm{~cm}$ (Figure 4(d)). In zone II, Detarium senegalense has a bell structure with a dominance of intermediate species (Figure 4(a)). Class distribution of Detarium senegalense diameter reveals a predominance of tree diameter classes between 30 and $70 \mathrm{~cm}$. Indeed $50 \%$ of Detarium senegalense have a $\mathrm{DBH} \leq 53.2 \mathrm{~cm}$ and $75 \%$ of trees with a diameter less than $65.8 \mathrm{~cm}$ (Table 4). Small diameter trees $(10 \mathrm{~cm} \leq \mathrm{DBH} \leq 30 \mathrm{~cm})$ are very few represented. The largest individuals of diameter between 70 and $90 \mathrm{~cm}$ and those of more than $90 \mathrm{~cm}$ diameter are also poorly represented in the stand. The distribution of Detarium senegalense in the area IV is similar to that of Zone II 
Table 3. Silvicultural characteristics of Detarium senegalense individuals of $\mathrm{DBH} \geq 10 \mathrm{~cm}$ observed in ecological zones II, IV and V of Togo.

\begin{tabular}{cccccc}
\hline \multirow{2}{*}{ Structural parameters } & \multicolumn{3}{c}{ Zones } & \multirow{2}{*}{ p-value } \\
\cline { 3 - 5 } & & Zone II & Zone IV & Zone V* & \\
\hline Tree observed (n) & Nomber & 20 & 97 & 25 & - \\
Mean DBH (cm) & Mean \pm STDEV & $54.8 \pm 21.4$ & $63.5 \pm 19$ & $43 \pm 9.6$ & \\
& CV (\%) & 39 & 29.9 & 22.6 & $4.3 \mathrm{e}-07<0.05$ \\
Mean height (m) & Mean \pm STDEV & $26 \pm 7.5$ & $21 \pm 5.7$ & $12.8 \pm 1.7$ & \\
& CV (\%) & 28.8 & 27.1 & 13.3 & $1.6 \mathrm{e}-11<0.05$ \\
Quartile diameters & $25 \%$ & 37.9 & 49.75 & 36.5 & \\
$(\mathrm{~cm})$ & $50 \%$ & 53.2 & 63.75 & 43.0 & \\
& $75 \%$ & 65.8 & 75.75 & 50.8 & \\
\hline
\end{tabular}

${ }^{\star}$ Observation in a single forest (Have Forest).
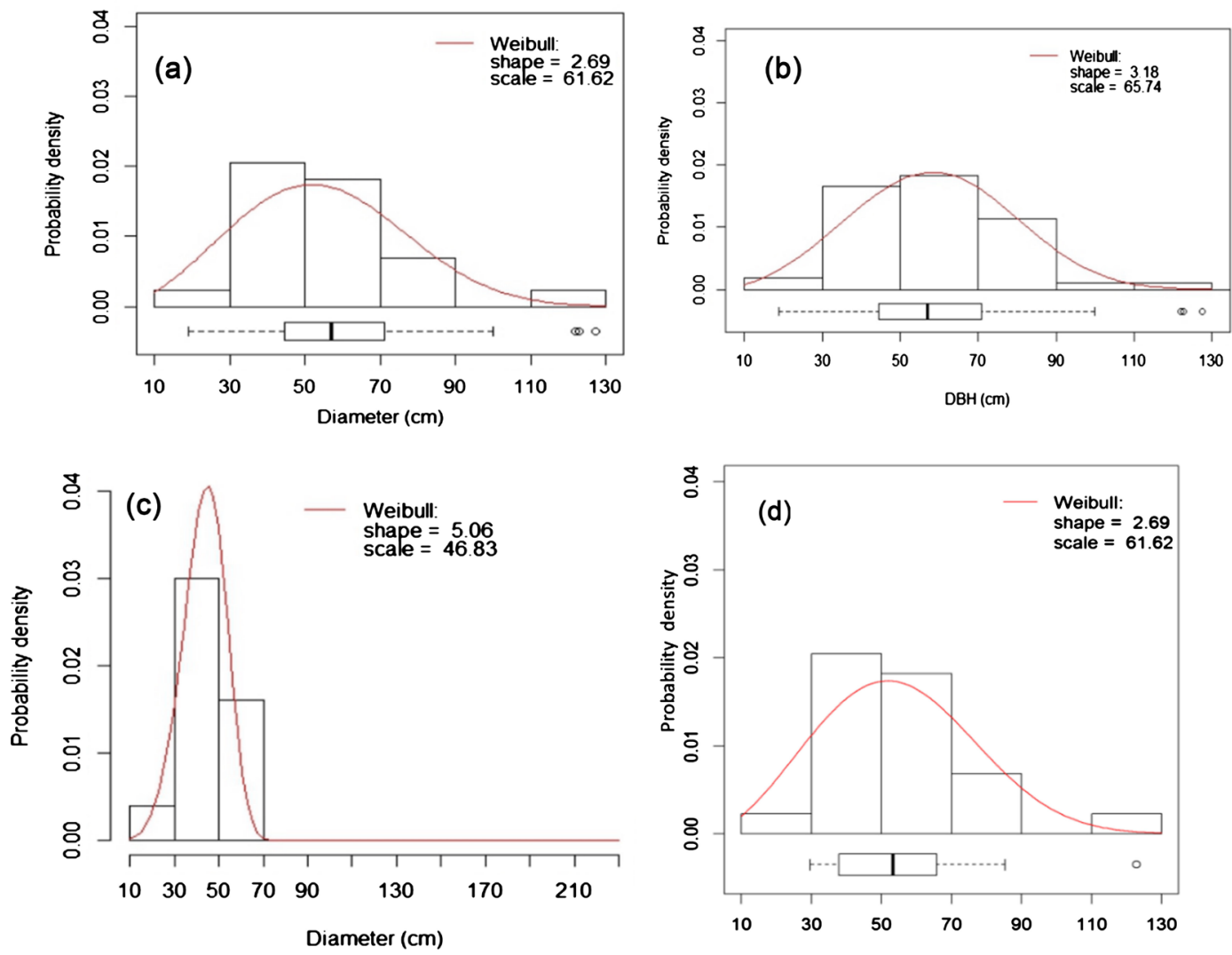

Figure 4. Diameter class distribution and boxplot Detarium senegalense in the ecological zone II (a), in the ecological zone IV (b), in the ecological zone V (c) in all 3 zones together (d).

with a dominance of the intermediate shafts and sometimes the presence of large trees (Figure $4(\mathrm{~b})$ ). In this zone, $50 \%$ of trees have a diameter less than or equal to $63.75 \mathrm{~cm}$ (Table 4 ).

In zone $\mathrm{V}$, the distribution of diameter of Detarium senegalense diameter classes reveals a predominance of tree diameter classes between 30 and $50 \mathrm{~cm}$ is 
the whole stand. Individuals with a diameter between 50 and 70 are present but rather those with diameters greater than $70 \mathrm{~cm}$ are very rare. Also small individuals of diameter between 10 and $30 \mathrm{~cm}$ are more represented in this area than in other areas (Figure $4(\mathrm{c})$ ). In this zone, $50 \%$ of individuals have a diameter less than or equal to $43 \mathrm{~cm}$ and $75 \%$ of individuals a diameter $50.8 \mathrm{~cm}$. Detarium senegalense faces regeneration problems. In this area the kind of individuals are located in one place where they are an aggregate in "Have" forest. The distribution of Detarium senegalense in all ecological zones put together has a bell-shaped structure with an absence of small specimens with a diameter between 10 and 30 $\mathrm{cm}$ (Figure 4(d)). The ecological zone II and IV have similar distributions with dominance of the intermediate shafts and sometimes the presence of large trees. However, the zone V (savanna) is characterized by a lack of big trees.

\subsection{Structure of All Species Compared to Detarium senegalense Structure}

In all ecological zones put together, $50 \%$ of Detarium senegalense trees have a $\mathrm{DBH} \leq 56.8 \mathrm{~cm}$ while $50 \%$ of all species inventoried have $\mathrm{DBH} \leq 33.25 \mathrm{~cm}$. Detarium senegalense trees inventoried have higher $\mathrm{DBH}$ than other species inventoried. In all ecological zones, the diameters of Detarium senegalense individuals are significantly different from those of other species. Indeed, the statistical test of Kruskal gives $\mathrm{P}$ values are less than the threshold alpha of 0.05 in all ecological areas (Table 4).

\subsection{Regeneration of Detarium senegalense}

Natural regeneration of Detarium senegalense is very low and less than $20 \%$ in all the ecological zones (Table 5). Detarium senegalense stand consists mainly of

Table 4. Kruskal statistical test result for the comparison of the diameter and height of Detarium senegalense and other species in different ecological zones.

\begin{tabular}{ccc}
\hline & p-value de Kruskal test \\
\hline Ecological zone & \\
\hline Zone II & Zone IV & Zone V \\
\hline
\end{tabular}

Comparison of Detarium senegalense diameters with those of other species

$$
2.74 \mathrm{e}-07<0.001 \quad 2.2 \mathrm{e}-16<0.001 \quad 1.52 \mathrm{e}-08<0.001
$$

Comparison of Detarium senegalense heights with those of other species

$1.13 \mathrm{e}-07<0.001 \quad 2.2 \mathrm{e}-16<0.001 \quad 3.28 \mathrm{e}-07<0.001$

${ }^{*} \mathrm{P}$-value $<0.001$ then the diameters and heights of Detarium senegalense are significantly different from those of other species; P-value $>0.05$ then the diameters and heights of Detarium senegalense are not significantly different from those of other species.

Table 5. Regeneration rate of Detarium senegalense by ecological zone.

\begin{tabular}{cccc}
\hline & \multicolumn{3}{c}{ Ecological zone } \\
\cline { 2 - 4 } & Zone II & Zone IV & Zone V \\
\hline Regeneration rate (\%) & 19.06 & 17.09 & 10.86 \\
\hline
\end{tabular}


intermediate trees $(30-50 \mathrm{~cm})$ with few big trees.

In addition, in all ecological areas, Detarium senegalense trees have a bell structure with the largest number of individuals in intermediate diameters classes. Detarium senegalense is facing regeneration problems likely due to the pressure on the resource. Germination tests showed that Detarium senegalense seeds germinate very easily. Indeed, 15 seeds have germinated out of 21 selected, which give a germination rate of $71 \%$. This experience shows that Detarium senegalense regenerates by seed but does not survive under conditions encountered in different areas.

\section{Discussion}

Data collected shown that Detarium senegalense is present in the ecological zones II, III, IV and V of Togo. Detarium senegalense is found in the ecological zone II, III and IV [19]. No prior information except that performed in this study has confirmed the presence of Detarium senegalense in the ecological zone $\mathrm{V}$ so far. This is probably due to the fact that in this area the species is only found in a forest. From the study we noted that Detarium senegalense is more frequent in gallery forest or along river. According to [28] study Detarium senegalense trees are typically found growing along river banks. Detarium senegalense density is low in all the ecological zones $(0.13 \mathrm{n} / \mathrm{ha})$. Similar results were found in Sierra Leone where trees of Detarium senegalense DBH greater than 60 $\mathrm{cm}$ have a density between 0.025 and $0.15 \mathrm{n} / \mathrm{ha}$ [15]. The low regeneration rate of Detarium senegalense can be explained by the pressure local people apply on specie but also on forest ecosystems in general. Often in the rural area, the undergrowth trees are turned into subsistence or cocoa farming in certain ecological areas (especially in zone IV). This pressure has a double impact on the distribution of the specie. First, it explains the abundance of individuals with intermediate and big diameters (fruit growers) and the low regeneration of Detarium senegalense due to the regular collection of fruits [30]. Detarium senegalense trees in the ecological zone II (National Park Fazao Malfakassa), have the highest medium height and diameter. In this area, subject to conservation and protection, Detarium senegalense trees do not seem to be endangered by human activities. However, regeneration of Detarium senegalense is low also in this area due to illegal intrusion of people who routinely pick up the seeds [30]. In zone $\mathrm{V}$ (savannah), Detarium senegalense trees have the lowest average DBH (43 \pm 9.6 $\mathrm{cm})$ and average height $(12.8 \pm 1.7 \mathrm{~m})$ in the study area. Therefore, Detarium senegalense individuals found in savannah in "Have" forest are composed of trees of small sizes while in forest, interspecific competition means fewer trees, but these are larger. The same result was found in the settlement of Pterocarpus erinaceus in Benin [31]. Detarium senegalense trees have a unimodal distribution. According to [29], unimodal distributions are characteristic of even-aged stands and the shape of the curve reveals the events related to the life of stands. This allows to state that Detarium senegalense trees are close in age [29]. This 
bell-shaped distribution can also be explained by the collection of fruit that affects the regeneration rate of the specie and the fact that the bigger trees are not cut. The same conclusions were drawn by research in Benin whose showed that an uneven-aged stand subjected to various pressures may also have unimodal allure [31].

The low regeneration rate of Detarium senegalense despite the abundance of fruit produced each year is likely due to the pressure by the systematic collection of fruits [30]. According to [32], harvesting fruits changes the regenerative capacity of a specie with sexual reproduction. This is the case of Detarium senegalense with sexual reproduction. Also, the use of fire as a tool for agricultural practices probably has a direct impact on the regeneration of all tree species in the area. The low rate of regeneration may be also caused locally by overgrazing and transhumance in the area. The negative impact of human as well as grazing animals on the resource have been identified by several studies in the sub-region [33]. The conversion of land to other uses has a great impact on the regeneration of species like Detarium senegalense. Indeed, the different inventoried areas are characterized by a conversion of forests to agriculture land. Therefore, each year, a portion of fallow or forest is cleared with fire for permanent agriculture [34]. Finally, the seeds of Detarium senegalense are subject to international trade between the villages of the study area and Nigeria where there is high demand for the fruits [30]. Therefore, one can assume that traders are interested in the best fruits and those that remain in forests are with defects, therefore, with a low germination capacity. Detarium senegalense can be used in agroforestry system as in Senegal where it is planted in combination with Neocarya macrophylla in agroforestry programs [15]. The average density in these agroforestry systems is 17 individuals/ha.

\section{Conclusion}

This study describes the main ecological characteristics of Detarium senegalense in Togo. The data generated by this study are a useful source of information for the sustainable management of the specie in Togo. Detarium senegalense is more common in the ecological zones II, IV, and V. In terms of abundance Detarium senegalense is more abundant in the zone $\mathrm{V}$ (savannah) where it is more located in one place. This distribution is influenced not only by environmental factors, but also by the systematic collection of seeds in zone II and IV. The demographic structure of the species is a bell with a predominance of intermediate diameter individuals. Low diameter individuals are very rare even in stands were larger trees are relatively abondant, indicating its low regeneration rate in different ecological zones and formations. Detarium senegalense faces regeneration problems likely due to unfavourable conditions such as the systematic collection of fruits. However, the main reason is human activities, as fruits and seeds have both, subsistence and commercial value and are intensively collected. Detarium senegalense trees are threatened with extinction if nothing is done to ensure 
their regeneration in forests. It is therefore important to implement an assisted natural regeneration and seedlings protection of Detarium senegalense to ensure its renewal. The pressure on Detarium senegalense within the forest could be reduced if the specie were domesticated by local population. Detarium senegalense can also be used for enrichment in agroforestry systems or afforestation plantations. Thus, it is necessary to support the improvement of the methods of sustainable harvest of the specie. Therefore, the challenge is how to integrate local use, ecological behavior, forest law and agricultural activities into the management of NTFPs in general and of Detarium senegalense in particular. The success of this process will depend of all actors, including policymakers, technicians, local people, researchers, extension agencies and funding agencies. The role of each actor must be defined beforehand.

\section{Acknowledgements}

The authors would like to express sincere thanks to African Forest Forum (AFF) for their financial support to this work.

\section{Conflicts of Interest}

The authors declare no conflicts of interest regarding the publication of this paper.

\section{References}

[1] Wilkie, D. (2000) Le programme du CARPE (Programme Regional pour l'Environnement en Afrique Centrale) sur les produits forestiers non ligneux.

[2] Falconer, J. and Koppell, C.R. (1990) The Major Significance of "Minor" Forest Products. The Local Use and Value of Forests in the West African Humid Forest Zone. Community Forestry Note (FAO).

[3] Pendje, G., Malanda, B. and Kabala, M.D. (1992) La réserve de biosphère de Luki (Mayombe, Zaïre): Patrimoine floristique et faunique en péril. UNESCO.

[4] Ndoye, O., Ruiz-Perez, M. and Eyebe, A. (1999) Non-Wood Forest Products Markets and Potential Degradation of the Forest Resource in Central Africa: The Role of Research in Providing a Balance between Welfare Improvement and Forest Conservation.

[5] Ndoye, O. (1995) The Market for Non-Timber Forest Products in the Humid Zone of Cameroon and Its Borders: Structure, Conduct, Performance and Policy Implications. Report to CIFOR, Bogor.

[6] Neumann, R.P. and Hirsch, E. (2000) Commercialisation of Non-Timber Forest Products: Review and Analysis of Research. Cifor.

[7] Belcher, B.M. and Vantomme, P. (2003) What Isn't an NTFP? The International Forestry Review, 5, 161-168. https://doi.org/10.1505/IFOR.5.2.161.17408

[8] Agbelade, A.D. and Onyekwelu, J.C. (2013) Poverty Alleviation through Optimizing the Marketing of Garcinia kola and Irvingia gabonensis in Ondo State, Nigeria. ISRN Forestry.

[9] Heubes, J., Heubach, K., Schmidt, M., Wittig, R., Zizka, G., Nuppenau, E.A. and Hahn, K. (2012) Impact of Future Climate and Land Use Change on Non-Timber 
Forest Product Provision in Benin, West Africa: Linking Niche-Based Modeling with Ecosystem Service Values. Economic Botany, 66, 383-397. https://doi.org/10.1007/s12231-012-9216-1

[10] Malleson, R., Asaha, S., Egot, M., Kshatriya, M., Marshall, E., Obeng-Okrah, K. and Sunderland, T. (2014) Non-Timber Forest Products Income from Forest Landscapes of Cameroon, Ghana and Nigeria-An Incidental or Integral Contribution to Sustaining Rural Livelihoods? International Forestry Review, 16, 261-277. https://doi.org/10.1505/146554814812572449

[11] Ticktin, T. (2004) The Ecological Implications of Harvesting Non-Timber Forest Products. Journal of Applied Ecology, 41, 11-21. https://doi.org/10.1111/j.1365-2664.2004.00859.x

[12] Akpagana, K. (1989) Recherches sur les forêts denses humides du Togo. Thèse de Doctorat, Université de Bordeaux III, U.F.R. Aménagement et Ressources Naturelles.

[13] Adjossou, K. (2009) Diversité, structure et dynamique de la végétation dans les fragments de forêts humides du Togo: Les enjeux pour la conservation de la biodiversité. Université de Lomé.

[14] Burkill, H.M. (1994) The Useful Plants of West Tropical Africa. Volume 2, Families EI, Royal Botanic Gardens.

[15] El-Kamali, H.H. (2009) Ethnopharmacology of Medicinal Plants Used in North Kordofan (Western Sudan). Ethnobotanical Leaflets, 2009, 24.

[16] Diop, N., Ndiaye, A., Cisse, M., Dieme, O., Dornier, M. and Sock, O. (2010) Le ditax (Detarium senegalense JF Gmel.): Principales caractéristiques et utilisations au Sénégal. Fruits, 65, 293-306. https://doi.org/10.1051/fruits/2010025

[17] Irvine, F.R. (1961) Woody Plants of Ghana with Special Reference to Their Uses.

[18] National Research Council (1996) Lost Crops of Africa: Volume I: Grains. National Academies Press, Washington DC.

[19] Atato, A., Wala, K., Batawila, K., Woegan, A.Y. and Akpagana, K. (2010) Diversité des fruitiers ligneux spontanés du Togo. Fruit, Vegetable and Cereal Science and Biotechnology, 4, 1-9.

[20] Endress, B.A., Gorchov, D.L., Peterson, M.B. and Padron Serrano, E. (2004) Harvest of the Palm Chamaedorea radicalis, Its Effects on Leaf Production, and Implications for Sustainable Management. Conservation Biology, 18, 822-830. https://doi.org/10.1111/j.1523-1739.2004.00073.x

[21] Biloso, M.A. (2008) Valorisation des produits forestiers non ligneux des plateaux de Batéké en périphérie de Kinshasa (RD Congo). Thèse de Doctorat, Université Libre de Bruxelles, Faculté des sciences, service d'écologie du Paysage et Système de Production Végétale.

[22] Fedoung, F.E., Ngansop, M., Zapfack, L., Kemeuze, V.A., Sonwa, D.J., Nguenang, G.M. and Nkongmeneck, B.A. (2014) Density and Natural Regeneration Potential of Selected Non-Timber Forest Products Species in the Semi-Deciduous Rainforest of Southeastern Cameroon. African Study Monographs, 49, 69-90.

[23] Kebenzikato, A.B., Wala, K., Dourma, M., Atakpama, W., Dimobe, K., Pereki, H., Batawila, K. and Akpagana, K. (2014) Distribution et structure des parcs à Adansonia digitata L. (baobab) au Togo (Afrique de l'Ouest). Afrique Science: Revue Internationale des Sciences et Technologie, 10.

[24] Arbonnier, M. (1990) Étude d'une savane graminéenne et forestière en vue de son aménagement à partir du cas de Koumpentoum (Sénégal). PhD Thesis, Nancy 1.

[25] Adjonou, K., Bellefontaine, R. and Kokou, K. (2009) Les forêts claires du Parc 
national Oti-Kéran au Nord-Togo: Structure, dynamique et impacts des modifications climatiques récentes. Science et changements planétaires/Sécheresse, 20, 394-396.

[26] Adjossou, K. (2009) Diversité, structure et dynamique de la végétation dans les fragments de forêts humides du Togo: Les enjeux pour la conservation de la biodiversité. Togo. Thèse de Doctorat. Université de Lomé.

[27] Kokou, K., Nuto, Y. and Adjonou, K. (2008) Restaurer les forêts tropicales africaines avec les espèces locales: Cas de Nauclea diderrichii dans le Litimé (Sud Est des Monts du Togo). 5-24.

[28] Rothe, P.L. (1948) Régénération naturelle en forêt tropicale: Le Dipterocarpus dyeri (Dau) sur le versant cambodgien du golfe du Siam. Bois \& Forets des Tropiques, 8 , 368-370.

[29] Rondeux, J. (1999) La mesure des arbres et des peuplements forestiers. Les presses agronomiques de Gembloux.

[30] Dangbo, F. (2015) Detarium senegalense: Rôle socio-économique et durabilité écologique au Togo. Suisse. Mémoire de Master. Bern University of Applied Science (HAFL).

[31] Glele Kakaï, R.L., Sinsin, B. and Palm, R. (2008) Etude dendrométrique de Pterocarpus erinaceus Poir. Des formations naturelles de la zone soudanienne au Bénin. Agronomie Africaine, 20.

[32] Avocèvou-Ayisso, C., Sinsin, B., Adégbidi, A., Dossou, G. and van Damme, P. (2009) Sustainable Use of Non-Timber Forest Products: Impact of Fruit Harvesting on Pentadesma butyracea Regeneration and Financial Analysis of Its Products Trade in Benin. Forest Ecology and Management, 257, 1930-1938. https://doi.org/10.1016/j.foreco.2009.01.043

[33] Ouoba, P. (2006) Flore et végétation de la forêt classée de Niangoloko, sud-ouest du Burkina Faso. Thèse unique de doctorat, Université de Ouagadougou, Ouagadougou, 139.

[34] MERF (Ministère de L'Environnement et des Ressources Forestières) (2013) Proposition de Mesures pour l'etat de preparation (R-PP). Fonds de partenariat pour le carbone forestier (FCPF), Ministère de l'Environnement et des Ressources Forestières, Togo. 